\title{
Genetic and biological characterization of nine Streptococcus salivarius subsp thermophilus bacteriophages
}

\author{
D Larbi, C Colmin, L Rousselle, B Decaris, JM Simonet * \\ Laboratoire de génétique et microbiologie, faculté des sciences, université Nancy I, \\ BP 239, 54506 Vandœuvre-lès-Nancy, France
}

(Received 17 July 1989; accepted 4 January 1990)

\begin{abstract}
Summary - Nine bacteriophages of Streptococcus salivarius subsp thermophilus isolated from different fermentation accidents, with different geographic origins, were compared according to their genomic structures and growth characteristics. Their genomes are linear, double-stranded DNA, with complementary cohesive ends. They belong to one group and are classed into 2 closely related strains. The phages of the same strain show the same restriction pattern with BamHI, EcoRI, HindIII and $P v u$ II. The bacteriophages $\phi \mathrm{B} 1.2$ and $\phi \mathrm{A} 1.1$ representative of the strain 1 and strain 2 respectively were characterized and compared according to their morphology, growth characteristics, restriction maps and DNA homology. They belong to Bradley's group B. The optimum concentration of $25 \mathrm{mM}$ was determined for phage infections requiring calcium ions. One-step growth studies show that the latent period is 25 min for both $\phi \mathrm{A} 1.1$ and $\phi \mathrm{B} 1.2$; their burst size is 88 and 56 particles per infected cell, respectively. Their genomes are $36.2 \pm 0.5$ and $35.6 \pm 0.5 \mathrm{kbp}$ in length, respectively. The restriction maps of these genomes are constructed. Cross-hybridization experiments showed that the 2 bacteriophages are closely related. Using Southern blot hybridization, no homology was detected between the DNA of various bacterial strains, ie, strains sensitive or resistant to phage infections, and the $\phi \mathrm{B} 1.2 \mathrm{DNA}$, indicating that these bacteria are not lysogenic for these phages.
\end{abstract}

bacteriophage / Streptococcus salivarius subsp thermophilus / restriction map / DNA homology / growth characteristic / morphology

Résumé - Caractérisation génétique et biologique de 9 bactériophages de Streptococcus salivarius subsp thermophilus. L'analyse des profils de restriction de 9 bactériophages issus d'accidents de fabrication et d'origines géographiques différentes a montré une parenté entre ces phages. Leurs génomes sont linéaires avec des extrémités cohésives. Ils ont été classés en 1 seul groupe contenant 2 souches, chaque souche étant caractérisée par un même profil de restriction obtenu avec les endonucléases BamHI, EcoRI, Hindlll et Pvull. Les bactériophages $\phi B 1.2$ et $\phi A 1.1$ correspondant respectivement à la souche 1 et 2 ont été étudiés au niveau morphologique, biologique et génétique. Ils appartiennent au groupe $B$ de Bradley. Leurs caractéristiques de croissance ont été définies. Ils nécessitent la présence d'ions $\mathrm{Ca}^{2+}$, la concentration optimale de $\mathrm{CaCl}_{2}$ étant de 25 $\mathrm{mM}$. La durée de leur cycle de multiplication est de $25 \mathrm{~min}$. La taille de la récolte est de 88 particules par cellule infectée pour $\phi B 1.2$ et de 56 particules par cellule infectée pour $\phi A 1.1$. La taille du génome de $\phi A 1.1$ est de $36,2 \pm 0,5 \mathrm{~kb}$ et celle de $\phi B 1.2$ est de $35,6 \pm 0,5 \mathrm{~kb}$. La cartographie de ces génomes montre une grande ressemblance, qui a été confirmée par hybridation $A D N-A D N$. Des expériences d'hybridation utilisant comme sonde l'ADN de $\phi B 1.2$ ne révèlent aucune homologie de séquence avec les génomes des bactéries industrielles, sensibles et résistantes, ce qui indique que ces bactéries ne sont pas lysogènes pour les bactériophages étudiés.

bactériophage / streptococcus salivarius subsp thermophilus / carte de restriction / homologie d'ADN / caractéristique de croissance / morphologie

* Correspondence and reprints 


\section{INTRODUCTION}

Bacteriophage attack is one of the primary causes of slow acid production by lactic acid bacteria during industrial fermentation. Thus, extensive investigations have been carried out on phages and phageresistance mechanisms, especially for the mesophilic N streptococci (Daly, Fitzgerald, 1987; Klaenhammer, 1987; Teuber, Loof, 1987; Mata, Ritzenthaler, 1988; Sanders, 1988). Conversely, little is known about phages and phage-resistance mechanisms in $S$ salivarius subsp thermophilus. Studies based on the host range, structural proteins, serological and morphological properties were carried out (Kivi et al, 1987). The effect of incubation temperature on the development of $S$ salivarius subsp thermophilus and its phages was studied (Sozzi et al, 1978). Their morphology has been investigated in several works (Accolas, Spillmann, 1979; Reinbold, Reddy, 1982; Krusch et al, 1987). On the basis of DNA homology and electrophoretic patterns of the structural proteins, 12 virulent phages of $S$ salivarius subsp thermophilus were classified in the single phage species (Mata, Ritzenthaler, 1988). A DNA homology between virulent phages of $S$ salivarius subsp thermophilus was also demonstrated by Benbadis et al (1987) and Neve et al (1989).

In this report, 9 bacteriophages isolated from abnormal fermentations, with various geographic origins, were classed into 1 group containing 2 closely related strains according to their restriction patterns. The phages $\phi \mathrm{A} 1.1$ and $\phi \mathrm{B} 1.2$ corresponding to the 2 different strains were further studied at both biological and genetic levels.

\section{MATERIALS AND METHODS}

\section{Phage and bacterial strains}

The streptococcus salivarius subsp thermophilus strains used in this study are listed in table I. The strains were grown on M17 broth (Terzaghi and Sandine, 1975 ) at $42{ }^{\circ} \mathrm{C}$ from $1 \%$ subcultures in reconstituted milk (10\%). M17 solid media ( $1.5 \%$ agar) and soft agar ( $0.5 \%$ agar) were used. The phages used in this study and their geographic origins are listed in table I. They were isolated from abnormal fermentations. The lysates were prepared by propagating these phages on the NST3 strain.

\section{Host range determination}

The phage host range was determined by plating up to $10^{8} \mathrm{PFU}$ (plaque forming units) on a lawn of the tested bacterial strain (table I) at $42^{\circ} \mathrm{C}$ in the presence of $25 \mathrm{mM} \mathrm{CaCl}_{2}$.

\section{Determination of $\mathrm{CaCl}_{2}$ optimum concentration for infection}

Plaque forming units (PFU) of the phage lysates were determined in the presence of different concentrations of $\mathrm{CaCl}_{2}$ according to the technique described by Accolas and Spillmann (1979).

\section{Preparation of phage lysates}

The bacterial strains were grown in M17 broth and harvested in early growth logarithmic phase. The culture sample was then incubated with the phage at a multiplicity of infection (MOI) of $\approx 0.3$ in the presence of $25 \mathrm{mM} \mathrm{CaCl}_{2}$ at $37^{\circ} \mathrm{C}$ for $15 \mathrm{~min}$. The mixture was then diluted $(1 / 10)$ by the addition of 9 vol of prewarmed M17 broth and incubated at $42^{\circ} \mathrm{C}$ until lysis oc- 
curred. The phage lysate was then filtered (Millipore, pore size $0.45 \mu \mathrm{m}$ ) and treated by DNase (Sigma) at a final concentration of $5 \mu \mathrm{g} / \mathrm{ml}$, RNase (Sigma) $(10 \mu \mathrm{g} / \mathrm{ml})$, and lysozyme (Boehringer Mannheim) $(50 \mu \mathrm{g} / \mathrm{ml})$, at $37^{\circ} \mathrm{C}$ for $30 \mathrm{~min}$. The determination of plaque forming units (PFU) of phage lysate was carried out by using the double agar layer technique.

Table I. Bacterial strains and bacteriophages used in this study and their origins. ATCC : American Type Culture Collection; CNRZ : Centre National de la Recherche Zootechnique; IP : Institut Pasteur.

Bactéries et bactériophages utilisés dans cette étude.

\begin{tabular}{|c|c|}
\hline Bacterial strain & Origin \\
\hline NST1 & Industrial strain \\
\hline NST3 & Industrial strain \\
\hline NST5 & Industrial strain \\
\hline NST9 & Industrial strain \\
\hline ATCC19258 & ATCC \\
\hline ATCC14485 & ATCC \\
\hline ATCC19987 & ATCC \\
\hline CNRZ302 & CNRZ \\
\hline CNRZ368 & CNRZ \\
\hline CNRZ455 & CNRZ \\
\hline CNRZ388 & CNRZ \\
\hline CNRZ391 & CNRZ \\
\hline CNRZ7 & CNRZ \\
\hline CNRZ307 & CNRZ \\
\hline CNRZ385 & CNRZ \\
\hline CNRZ308 & CNRZ \\
\hline CNRZ160 & CNRZ \\
\hline CNRZ445 & CNRZ \\
\hline IP6631 & IP \\
\hline Phage & Geographical origin \\
\hline$\phi A 1.1$ & France \\
\hline$\phi \mathrm{B} 1.2$ & Egypt \\
\hline$\phi \mathrm{T} 12$ & Ireland \\
\hline$\phi \mathrm{T} 17$ & France \\
\hline$\phi T 58$ & Portugal \\
\hline$\phi \mathrm{T} 9$ & Portugal \\
\hline$\phi \mathrm{D} 1$ & Argentina \\
\hline$\phi T 21$ & France \\
\hline$\phi$ T33 & Argentina \\
\hline
\end{tabular}

\section{Determination of burst size}

A phage suspension was added to Streptococcus salivarius subsp thermophilus strain NST3 so that the MOI was $\approx 0.01$ in a total vol of $400 \mu \mathrm{l}$. Adsorption was allowed to continue to completion at $37^{\circ} \mathrm{C}$ for $15 \mathrm{~min}$. Cells were then immediately pelleted by centrifugation at $8000 \mathrm{~g}$ for $2 \mathrm{~min}$. The number of free phage particles in the supernatant was determined by titration. The cells were washed twice with prewarmed M17 broth and resuspended in $40 \mathrm{ml}$ of the same medium. The lysis of culture at $42^{\circ} \mathrm{C}$ was controlled by plating $0.1 \mathrm{ml}$ of the mixture at $10-\mathrm{min}$ intervals by using the double-layer technique. This experiment was repeated 3 times.

\section{Latent period determination}

The NST3 strain was infected by phages with a MOI of 3 in the liquid medium (M17) at $37^{\circ} \mathrm{C}$ in the presence of $25 \mathrm{mM} \mathrm{CaCl}_{2}$. Bacterial kinetic growth was determined by reading optical density at $650 \mathrm{~nm}$ until lysis occurred.

\section{Phage purification and electron micro- scopy}

Phages were concentrated by polyethylene glycol precipitation (Yamamoto et al, 1970), resuspended in TMG buffer (Tris $10 \mathrm{mM}$ Tris- $\mathrm{HCl}, 10$ $\mathrm{mM} \mathrm{MgSO}{ }_{4}, 0.01 \%$ gelatin, $\mathrm{pH} 7.4$ ) and were purified by preformed caesium chloride gradient (Maniatis et al, 1982) which were over-layered with $50 \%$ glycerol. The $\mathrm{CsCl}$ was removed by extensive dialysis against TMG buffer containing $0.5 \mathrm{M} \mathrm{NaCl}$. The phages were negatively stained with $2 \%$ uranyl acetate $(\mathrm{pH} 4.5)$ and examined under a Siemens 102 electron microscope.

\section{Phage and bacterial DNA purification}

Phages were concentrated by centrifugation of lysate at $45000 \mathrm{~g}$ for $2.5 \mathrm{~h}$. Purified phages in TE buffer (1 mM EDTA, $10 \mathrm{mM}$ Tris- $\mathrm{HCl}, \mathrm{pH}$ 8.0) were heated for $15 \mathrm{~min}$ at $65^{\circ} \mathrm{C}$ in the presence of $5 \mathrm{mM}$ EDTA and $0.1 \%$ sodium dodecyl 
sulfate (SDS). Then proteinase $\mathrm{K}$ (Boehringer) was added at the final concentration of $200 \mu \mathrm{g} /$ $\mathrm{ml}$ and the mixture was incubated for $30 \mathrm{~min}$ at $37^{\circ} \mathrm{C}$. Subsequently, protein extraction was carried out once with Tris- $\mathrm{HCl}$-saturated phenol (pH 7.5) and once with chloroform-isoamylalcohol $(24 / 1, V / N)$. DNA was precipitated with isopropanol at $-20^{\circ} \mathrm{C}$ in the presence of $0.3 \mathrm{M}$ sodium acetate. Bacterial DNA was purified as previously described (Marmur, 1961).

\section{Preparation of $\left.{ }^{32} P\right]$ labelled phage DNA and DNA-DNA hybridization}

Phage DNA was purified by the Geneclean process (Bio 101), and then labelled with [ $\left.\alpha-{ }^{32} \mathrm{P}\right]$ dCPT by using a nick-translation kit (Amersham) (Rigby et al, 1977).

Bacterial DNA $(3 \mu \mathrm{g})$ was digested by restriction endonucleases, the resulting fragments were separated by electrophoresis on a $0.8 \%$ agarose gel and transferred to a hybond- $\mathrm{N}$ membrane (Amersham) according to the Southern method (Southern, 1975). DNA fragments were covalently linked to the membrane by exposure to UV light for $5 \mathrm{~min}$. Membranes were then prehybridized at $42{ }^{\circ} \mathrm{C}$ for $4 \mathrm{~h}$, in $6 \times \mathrm{SSC}$ ( $1 \times \mathrm{SSC}=0.15 \mathrm{M}$ sodium chloride, $0.015 \mathrm{M}$ sodium citrate), $5 \times$ Denhart (Ficoll $0.1 \%$, bovine serum albumin $0.1 \%$, polyvinylpyrrolidone $0.1 \%), 0.5 \times$ SDS, $50 \%$ formamide and $200 \mu \mathrm{g} /$ $\mathrm{ml}$ denatured salmon sperm DNA. The ${ }^{32} \mathrm{P}$. labelled phage DNA $\left(8 \times 10^{6} \mathrm{cpm}\right)$ was then added. The hybridization was allowed for $14 \mathrm{~h}$ at $42^{\circ} \mathrm{C}$. The membrane was then washed; (i), twice in $2 \times$ SSC, $0.1 \%$ SDS at room temperature for $30 \mathrm{~min}$; (ii), 3 times at $60^{\circ} \mathrm{C}$ for $40 \mathrm{~min}$ in $0.1 \times$ SSC, $0.1 \%$ SDS; (iii), twice in $0.1 \times$ SSC at room temperature. Filters were then exposed to $X$-ray Hyperfilm (Amersham) with an intensifying screen. Hybridization between phage DNA $(0.5 \mu \mathrm{g})$ was assured in the same conditions.

\section{Restriction analysis of phage DNA}

Cleavages with restriction endonucleases were carried out according to suppliers' instructions (Boehringer Mannheim, Appligène). Digests were heated at $70^{\circ} \mathrm{C}$ for $10 \mathrm{~min}$, held in ice and loaded onto $0.5-1 \%$ agarose horizontal slab gels in TAE buffer $(0.04 \mathrm{M}$ Tris acetate, $2 \mathrm{mM}$ EDTA, pH 8.0), and electrophoresis was performed for $16 \mathrm{~h}$ at $1 \mathrm{~V} / \mathrm{cm}$. A HindlII digest of lambda DNA was used as a molecular weight standard.

\section{RESULTS}

\section{Host range}

The ability of the 9 bacteriophages to propagate on 19 strains (table I) was tested. Identical lytic patterns were observed for the 9 phages. All phages were able to propagate only on the NST3 and NST5 strains. Thus, the other strains were inappropriate hosts to propagate these phages.

\section{Comparison of restriction patterns and structure of phage genomes}

The phage DNA were digested by BamHI, EcoRI, HindIII, Pvull and analysed by agarose gel electrophoresis. The phages $\phi B 1.2, \phi T 9, \phi T 21, \phi T 33, \phi T 58$ and $\phi D 1$ have the same patterns of their genomes and were classed in the same phage strain: strain 1, while the phages $\phi A 1.1$, $\phi \mathrm{T} 12$, and $\phi \mathrm{T} 17$ corresponded to a second strain: strain 2. In order to determine whether the phage DNA has cohesive ends, it was digested with various endonucleases and subjected to heat treatment $\left(70^{\circ} \mathrm{C}\right.$ for $\left.10 \mathrm{~min}\right)$ and immediately loaded on agarose gel in the presence of unheated digests. In each digest, a minor band gave 2 fragments after heattreatment. We concluded that the heat dependent bands were end fragments. The phage genomes were linear with single stranded cohesive ends. This was confirmed by pretreating phage DNA with T4 DNA ligase prior to the digest (data not shown). 
Restriction maps of $\phi$ A1.1. and $\phi B 1.2$

The phages $\phi B 1.2$ and $\phi A 1.1$ corresponding to the strain 1 and 2 , respectively, were chosen for further studies. The DNA of each phage was digested by various endonucleases and the resulting fragments were separated on agarose gels. The phage DNA were not cleaved either by Kpnl or Smal. They were digested by Aval, BamHI, BgllI, EcoRI, HindlII, Sacl, Sall, $P$ vull and Xhol. Their genome sizes were estimated from restriction digests and cal-

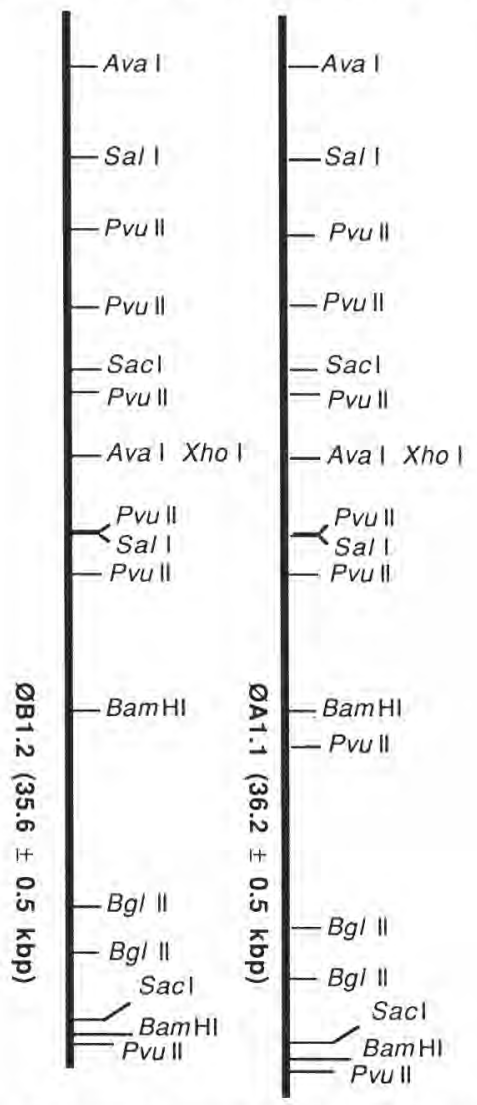

Fig 1. DNA restriction maps of $\phi A 1.1(36.2 \pm 0.5$ $\mathrm{kbp}$ ) and $\phi \mathrm{B} 1.2$ (35.6 kbp $\pm 0.5 \mathrm{kbp}$ ) genomes. Cartes de restriction des génomes de $\phi A 1.1$ $(36,2 \pm 0,5 \mathrm{kbp})$ et de $\phi B 1.2(35,6 \pm 0,5 \mathrm{kbp})$. (a)

(b)

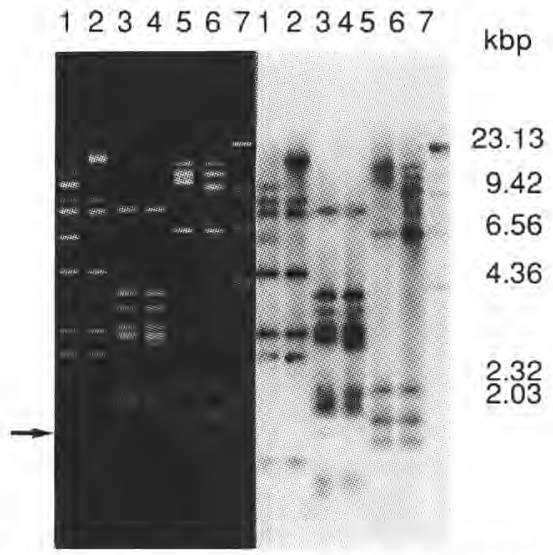

Fig 2. a), Digestion patterns of $\phi A 1.1$ and $\phi B 1.2$ DNA. Gel electrophoresis of EcoRI, HindII and Pvull digests of $\phi A 1.1$ and $\phi B 1.2$ genomes. b), Hybridization between $\phi A 1.1$ and $\phi B 1.2$ DNA. Autoradiogram prepared after hybridization of 32P-labeled DNA from phage $\phi B 1.2$ with phage DNA digests; lane 1, $\phi A 1.1$ DNA digested by Pvull; lane 2, фB1.2 DNA digested by Pvull; lane 3, фA1.1. DNA digested by HindIII; lane 4, ф1.2 DNA digested by Hindli; lane 5, $\phi A 1.1$ DNA digested by Eco RI; lane 6, $\$ B 1.2$ DNA digested by EcoRI; lane 7, Hindll digest of Lambda DNA. DNA digests were heated for $10 \mathrm{~min}$ at $70^{\circ} \mathrm{C}$ and separated by electrophoresis on agarose gel $(1 \%)$ for $16 \mathrm{~h}$ at $1 \mathrm{~V} / \mathrm{cm}$. A Hindll digest of lambda DNA was used as the molecular weight standard. The $1.5 \mathrm{kbp}$ Hind III fragment is indicated by arrows.

a) Profils de restriction des $A D N$ de $\phi A 1.1$ et de $\phi B 1.2$. Electrophorèse en gel d'agarose des génomes de $\phi A 1.1$ et $\phi B 1.2$ digérés par EcoRl, Hindlll et Pvull. b) Hybridation entre les ADN de $\phi A 1.1$ et $\phi B 1.2$. Autoradiographie préparée après hybridation avec $A D N$ du phage $\phi B 1.2$ marqué au ${ }^{32} P$; piste $1, A D N$ de $\phi A 1.1$ digéré par Pvull; piste 2, $A D N$ de $\phi B 1.2$ digéré par Pvull; piste 3, $A D N$ de $\phi A 1.1$ digéré par Hindlll; piste 4, $A D N$ de $\phi B 1.2$ digéré par Hindlli; piste 5 , ADN de $\phi A 1.1$ digéré par EcoRl; piste 6, $A D N$ de $\phi B 1.2$ digéré par EcoRl; piste 7, ADN du phage lambda digéré par Hindill. Les hydrolysats sont chauffés pendant $10 \mathrm{~min}$ à $70^{\circ} \mathrm{C}$ et séparés par électrophorèse en gel d'agarose (1\%) pendant $16 \mathrm{~h}$ à $1 \mathrm{~V} / \mathrm{cm}$. L'ADN du phage lambda digéré par HindllI est utilisé comme marqueur de taille. Le fragment Hindlll de 1,5 kpb est indiqué par une flèche. 
culated to be $35.6 \pm 0.5$ and $36.2 \pm 0.5$ $\mathrm{kbp}$, respectively. Restriction maps of the 2 phage genomes were obtained by mapping the sites for 7 endonucleases and by: i), identifying the heat-sensitive end fragments; ii), comparing single and double digests. The 2 phage genomes showed only minor differences (fig 1).

\section{Phage DNA homology}

DNA from $\phi$ B1.2 labeled with [ $\left.\alpha-{ }^{32} \mathrm{P}\right] \mathrm{dCTP}$ by nick-translation was used as a probe to hybridize to the phage DNA cleaved with Pvull, EcoRI and HindIII. The resulting au-

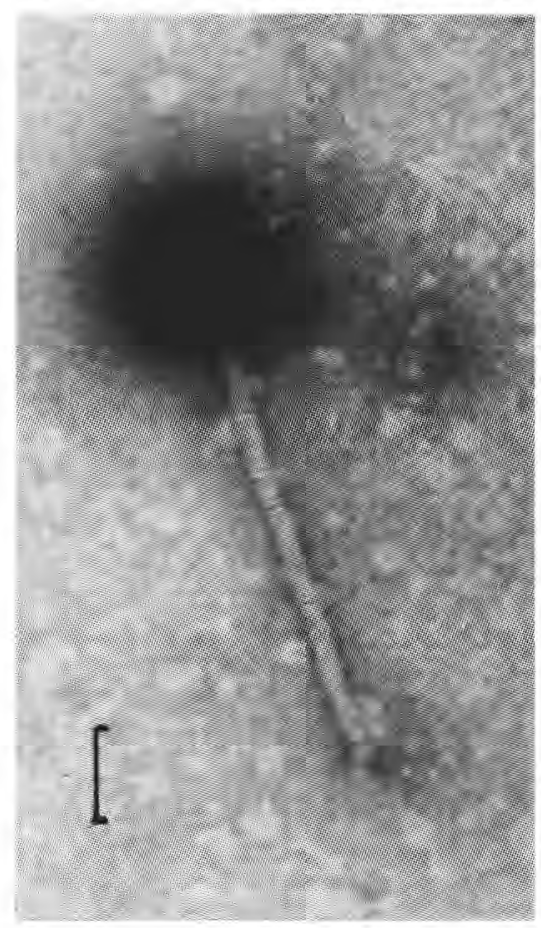

$\phi \mathrm{B} 1.2$ toradiogram was compared with the digestion patterns. Labeled DNA was able to hybridize strongly to all the restriction fragments except for the $\phi A 1.1$ DNA HindIII fragment of $1.5 \mathrm{kbp}$ (fig 2, lane 3). It is not likely that the difference lies only within this fragment, since partial homology between the probe and the restriction fragment is sufficient to allow hybridization.

\section{Phage morphology and biological prop- erties of $\phi A 1.1$ and $\phi B 1.2$}

The 2 bacteriophages belong to Bradley's group B (Bradley, 1967), with isometric

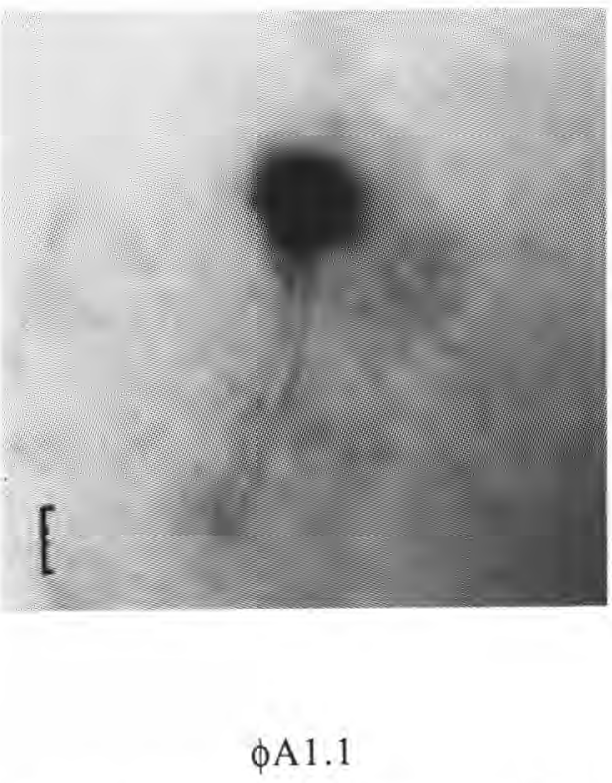

Fig 3. Electron micrographs of $\phi A 1.1$ and $\phi B 1.2$. Purified bacteriophages were negatively stained with $2 \%$ uranyl acetate; bar: $50 \mathrm{~nm}$.

Observation au microscope électronique des phages $\phi A 1.1$ et $\phi B 1.2$. Les bactériophages purifiés sont colorés négativement avec $2 \%$ d'acétate d'uranyle; barre, $50 \mathrm{~nm}$. 
heads and long non-contractile tails (fig 3 ). They possess a regular 6 -sided head (diameter $50 \pm 1 \mathrm{~nm}$ ), and the tail length was $246 \pm 5 \mathrm{~nm}$. The number of phages measured was 13 for $\phi A 1.1$ and 9 for $\phi B 1.2$. A terminal structure was observed, which appeared as a small plate.

Phage infections require the presence of the cations $\mathrm{Ca}^{2+}$. In the absence of $\mathrm{CaCl}_{2}$ the efficiency of plating considerably decreases and pinpoint plaques were observed (diameter $<0.5 \mathrm{~mm}$ ). The optimum concentration of $25 \mathrm{mM}$ was determined for the highest number of PFU (fig 4a). The growth cycle of the bacteriophages $\phi A 1.1$

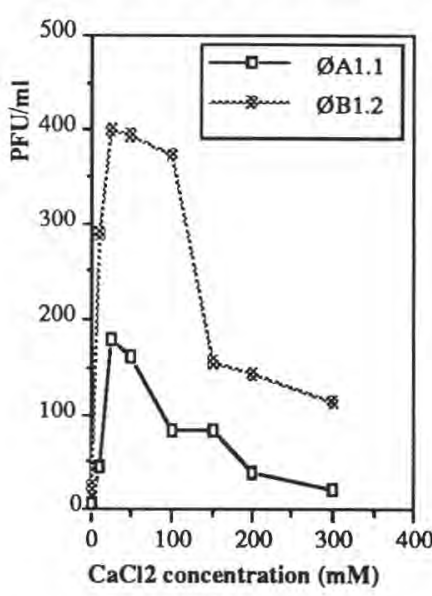

(a)

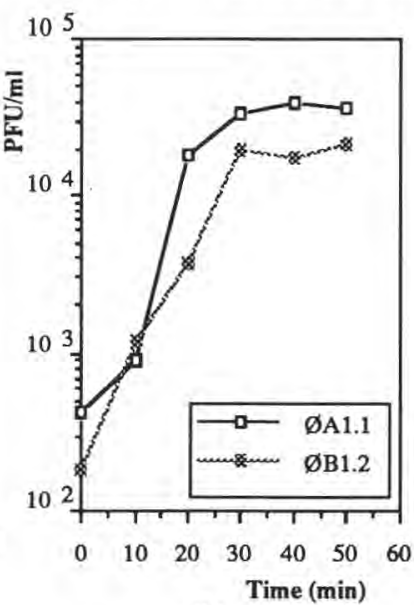

(b) and $\phi \mathrm{B} 1.2$ was characterized by a 1 -step growth on the NST3 strain under optimal conditions $\left.\left(42{ }^{\circ} \mathrm{C}, 25 \mathrm{mM} \mathrm{CaCl}\right)_{2}\right)$. Their burst size is 88 and 56 particles per cell, respectively (fig $4 \mathrm{~b}$ ). The latent period for the 2 bacteriophages is $25 \mathrm{~min}$ (fig $4 \mathrm{c}$ ).

\section{Hybridization between bacterial and phage DNA}

In order to determine whether bacterial strains resistant to $\phi B 1.2$ were lysogenic, a DNA-DNA hybridization experiment was carried out using $\phi \mathrm{B} 1.2$ DNA as a probe.

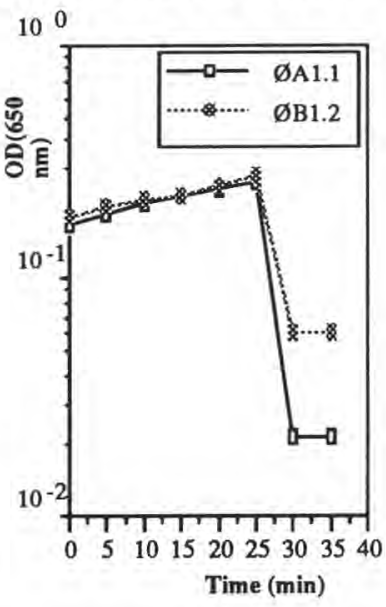

(c).

Fig 4. Biological properties of $\phi \mathrm{A} 1.1$ and $\phi \mathrm{B} 1.2$. a), The effect of $\mathrm{CaCl}_{2}$ concentration on the phage infections. Infective phages were numbered on NST3 strain, in M17 broth at $42{ }^{\circ} \mathrm{C}$, in the presence of different concentrations of $\mathrm{CaCl}_{2}$. b); One-step growth curves of bacteriophages $\phi \mathrm{A} 1.1$ and $\phi \mathrm{B} 1.2$. The phages were propagated on NST3 in M17 broth at $42^{\circ} \mathrm{C}$. Time 0 refers to the end of phage adsorption which was allowed for $15 \mathrm{~min}$ at $37^{\circ} \mathrm{C}$ and then diluted by 10 -fold dilution in prewarmed $\mathrm{M} 17$ broth. c), Latent period determination. NST3 was infected by phages with a $\mathrm{MOI}$ of 3 , at $37^{\circ} \mathrm{C}$, in the presence of $25 \mathrm{mM}$ of $\mathrm{CaCl}_{2}$. The infections were followed by reading optical density at $650 \mathrm{~nm}(\mathrm{OD}$, $650 \mathrm{~nm})$.

Propriétés biologiques de $\phi A 1.1$ and $\phi B 1.2$, a) Effet de la concentration en $\mathrm{CaCl}_{2}$ sur les infections phagiques. Les phages sont titrés sur la souche NST3, dans du milieu M17 à $42{ }^{\circ} \mathrm{C}$, en présence de différentes concentrations de $\mathrm{CaCl}_{2}$. b) Courbes de croissance en cycle unique des bactériophages $\phi A 1.1$ et $\phi B 1.2$. Les phages sont propagés sur NST3 dans du milieu M17 à $42{ }^{\circ} \mathrm{C}$. L'adsorption a lieu pendant 15 min à $37^{\circ} \mathrm{C}$ et le mélange est dilué 10 fois dans du milieu M17 préchauffé. c) Détermination de la durée du cycle de multiplication. La souche NST3 est infectée par les phages avec une multiplicité d'infection de 3 à $37^{\circ} \mathrm{C}$, en présence de $\mathrm{CaCl}_{2} 25 \mathrm{mM}$. Les infections sont suivies par lecture de la densité optique à $650 \mathrm{~nm}(D O, 650 \mathrm{~nm})$. 
Under the conditions used, no bacterial DNA sequence homologous to bacteriophage $\phi B 1.2$ DNA was detected (data not shown). Hybridization between sensitive strains and phage DNA do not show a homologous sequence either.

\section{DISCUSSION}

In this report, 9 bacteriophages of $S$ salivarius subsp thermophilus were differentiated according to their restriction patterns. Despite their different origins, they are closely related and are classed into 1 DNA homology group, containing 2 closely related phage strains. The phages of the same strain have the same restriction patterns. The same host range was observed for the 9 phages. Nevertheless, the determination of the efficiency of plating of the 9 bacteriophages on the sensitive bacterial strains showed that an identical restriction pattern did not imply the same host-phage interactions (unpublished results).

Krusch et al (1987), reported a country origin-specific host range; our results showed that the very related phages with identical host range can be detected throughout the world.

Comparison of restriction patterns of DNA strains with various endonucleases showed small but unambiguous differences between the bacterial strains studied (Colmin et al, 1987), notably between sensitive strains NST3 and NST5.

We determined the ability of $\phi \mathrm{B} 1.2$ to adsorb to strains NST1, NST3, NST5 and NST9. All these strains, except NST1, adsorb phage with an efficiency $>90 \%$. These indicate that NST9 resistance mechanism does not involve an alteration of the host ability to adsorb this phage. For NST1, adsorption appears to be restricted, indicating the absence of operational receptor (data not shown).
An electron microscopic examination confirmed the uniformity detected within the thermophilic streptococci described by Accolas and Spillmann (1979) and Krusch et al (1987). They belong to Bradley's group B.

Two phages $\phi \mathrm{B} 1.2$ and $\phi \mathrm{A} 1.1$ were characterized at both biological and genetic levels. Both require the divalent cation $\mathrm{Ca}^{2+}$ for effective infection. Many other bacteriophages have been reported to need divalent cations, usually $\mathrm{Ca}^{2+}$ or $\mathrm{Mg}^{2+}$ or both. They could be involved in different steps of the phage infection-cycle (Luria and Steiner, 1952; Watanabe and Takesue, 1972; Lawrence et al, 1976; Alatossova et al, 1987). In the case of $S$ salivarius subsp thermophilus, the role of $\mathrm{Ca}^{2+}$ though essential, is still unknown. Sozzi (1972) showed that the requirement of calcium for lysis is governed by the phagebacterium association and not only by the bacterium strain or the phage. The 2 phages have a similar latent period of $25 \mathrm{~min}$. These phages with fast multiplication and high burst size may cause complete failure of industrial cultures even if they are present in only low numbers at the beginning of the fermentation process. This could be an explanation for the extent of industrial problems related to such bacteriophages.

The latent period and burst size of several group $\mathrm{N}$ streptococci phages have been reported as a function of growth in different media and at different temperatures (Keogh, 1973). Latent periods in reconstituted milk ranged from $23-56 \mathrm{~min}$ at $30^{\circ} \mathrm{C}$, and from $16-44 \mathrm{~min}$ at $37^{\circ} \mathrm{C}$. Burst sizes were from $2-113$ particles at $30^{\circ} \mathrm{C}$ and from 0-139 particles at $37^{\circ} \mathrm{C}$ (Lawrence et al, 1976). The $\phi A 1.1$ and $\phi B 1.2$ latent periods and burst sizes were within these ranges. In industry, they depend on the factory and on physiological conditions of both host and phage. Studies on phage 
growth characteristics in standardized laboratory conditions are of fundamental importance, since they are still unknown. In addition, they provide an approach to predicting their behaviour in the factory.

The restriction mapping of $\phi A 1.1$ and $\phi B 1.2$ genomes show strong similarities. They differ in their size : $\phi \mathrm{A} 1.1$ is $0.6 \mathrm{kbp}$ larger than $\phi B 1.2$. The difference is localized in the BamHI-Bghl fragment of 7.6 $\mathrm{kbp}$ in $\phi \mathrm{A} 1.1$ genome and $7 \mathrm{kbp}$ in $\phi \mathrm{B} 1.2$ one. Cross-hybridization experiments show that this difference is probably contained in the $1.5 \mathrm{kbp}$ Hindlll fragment. These bacteriophages are closely related; 1 phage type could be derived from the other by a genomic rearrangement, eg deletion or insertion or both. The bacteriophages of lactic acid bacteria are frequently closely related; industrial fermentations might provide a dynamic situation inducing DNA exchanges. The presence of nonhomologous sequence flanked by homologous sequences could promote these DNA exchanges by homologous recombination (Mata and Ritzenthaler, 1988).

A close relationship between $S$ salivarius subsp thermophilus bacteriophages has also been described (Benbadis et al, 1987; Relano et al (cited as personal communication by Mata and Ritzenthaler, 1988, Neve et al, 1989). Twelve $S$ salivarius subsp thermophilus bacteriophages were differentiated into 3 subgroups by analysis of their genomes and structural proteins (Neve et al, 1989). A subgroup III of this classification consists of 9 phages with a genome size of $33.8-36.7 \mathrm{kbp}$. The studied phages may fit into this subgroup. DNA-DNA hybridization studies are needed to allow a molecular comparison between the $S$ salivarius subsp thermophilus phages so far studied. Selection of reference phages is necessary for establishing taxonomic studies (Mata, Ritzenthaler, 1988).
Hybridization experiments showed no homologous sequence between bacterial and viral DNA. Therefore, resistant bacteria were not lysogenic. Furthermore, absence of homology between bacterial and phage genome shows that the genomes of the bacterial strains we tested are not a potential source of the phage studied and related phages.

\section{ACKNOWLEDGMENTS}

We are grateful to Dr JC Guedenet for his assistance with the electron microscopy studies, and acknowledge financial support of the Ministère de la Recherche et de l'Enseignement Supérieur, the CNRS, the Université de Nancy I and the International Network of Biotechnology.

\section{REFERENCES}

Accolas JP, Spillmann H (1979) The morphology of six bacteriophages of Streptococcus thermophilus. J Appl Bacterio/ 47, 135-144

Alatossova T, Jütte H, Seiler H (1987) Transmembrane cation movements during infection of Lactobacillus lactis by bacteriophage LL-H. J Gen Virol 68, 1525-1532

Benbadis L, Faelen M, Castellino I, Fazel A, Mercenier A, Slos P (1987) Phages of Streptococcus thermophilus and Symposium on Lactic Acid Bacteria-Genetics, Metabolism and Applications, The Netherlands 22-25 September 1987. FEMS Microbiol Rev 46, 43

Bradley DE (1967) A review : ultrastructure of bacteriophages and bacteriocins. Bacteriol Rev 31, 230-340

Colmin C, Larbi D, Simonet JM Decaris B (1987) Strain identification in the genus Streptococcus by DNA restriction analysis. and Symposium on Lactic Acid Bacteria-Genetics, Metabolism and Applications. The Netherlands, 22-25 September 1987. FEMS Microbiol Rev 46,14

Daly C, Fitzgerald G (1987) Mechanisms of bacteriophage insensitivity in the lactic streptococci. In : Streptococcal Genetics. (Ferretti J, 
Curtis R III, eds) Am Soc Microbiol, Washington DC, 259-268

Keogh PB (1973) Adsorption, latent period and burst size of phages of some strains of lactic streptococci. J Dairy Res 40, 303-309

Kivi S, Peltomäki T, Luomala K, Sarimo SS (1987) Some properties of Streptococcus thermophilus bacteriophages. Folia Microbiol 32, 101-106

Klaenhammer TR (1987) Plasmid-directed mechanisms for bacteriophage defense in lactic streptococci. FEMS Microbiol Rev 46, 313-325

Krusch U, Neve H, Luschei B, Teuber M (1987) Characterization of virulent bacteriophages of $S$ salivarius subsp thermophilus by host specificity and electron microscopy. Kiel Milchwirtsch Forschungsber 39, 155-16

Lawrence RC, Thomas TD, Terzaghi BE (1976) Reviews of the progress of dairy science : cheese Starters. J Dairy Res 43, 141-192

Luria SE, Steiner DL (1954) The role of calcium in the penetration of bacteriophage T5 into its host. J Bacterio/ 67, 635-639

Maniatis ME, Fritsh EF, Sambrook J (1982) Molecular Cloning : A Laboratory Manual. Cold Spring Harbor Laboratory

Marmur J (1961) A procedure for the isolation of desoxyribonucleic acid from microorganisms. $\mathrm{J} \mathrm{Mol} \mathrm{Biol} \mathrm{3,} \mathrm{208-218}$

Mata M, Ritzenthaler P (1988) Present state of lactic acid bacteria phage taxonomy. Biochimie 70, 395-399

Neve H, Krusch U, Teuber M (1989) Classification of virulent bacteriophages of $S$ salivarius subsp thermophilus isolated from yoghurt and Swiss-type cheese. Appl Microbiol Biotechnol 30, 624-629
Reinbold GW, Reddy MS (1982) Ultrastructure of bacteriophages active against Streptococcus thermophilus, Lactobacillus bulgaricus, Lactobacillus lactis and Lactobacillus helveticus. J Food Prot 45, 119-124

Rigby PW, Dieckmann M, Rhodes C, Berg P (1977) Labelling desoxyribonucleic acid to high specific activity in vitro by nick translation with DNA polymerase I. J Mol Biol 113, 237-251

Sanders ME (1988) Phage resistance in lactic acid bacteria. Biochimie 70, 411-421

Southern EM (1975) Detection of specific sequence among DNA fragments separated by gel electrophoresis. J Mol Biol 98, 503-517

Sozzi T (1972) Etude de l'exigence en calcium des phages des ferments lactiques. Milchwissenschaft 27, 503-507

Sozzi T, Poulin JM, Maret R (1978) Effect of incubation temperature on the development of lactic acid bacteria and their phages. $J$ Dairy Res 45, 259-265

Terzaghi BE, Sandine WE (1975) Improved medium for lactic streptococci and their bacteriophages. Appl Microbiol 29, 807-813

Teuber M, Loof M (1987) Genetic characterization of lactic streptococcal bacteriophages. In: Streptococcal Genetics. (Ferrett J, Curtis R III, eds) Am Soc Microbiol, Washington, DC, $250-258$

Watanabe K, Takesue S (1972) The requirement for calcium in infection with Lactobacillus phage. J Gen Virol 17, 19-30

Yamamoto KR, Alberts BM, Benzinger R, Law-horme L, Treinber G (1970) Rapid bacteriophage sedimentation in the presence of polyethylene glycol and its application to large-scale virus purification. Virology 40 , 734-744 